\title{
Notes on Nursing: Nurses Making a Difference in Global Health
}

\author{
Regina Aparecida Garcia de Lima
}

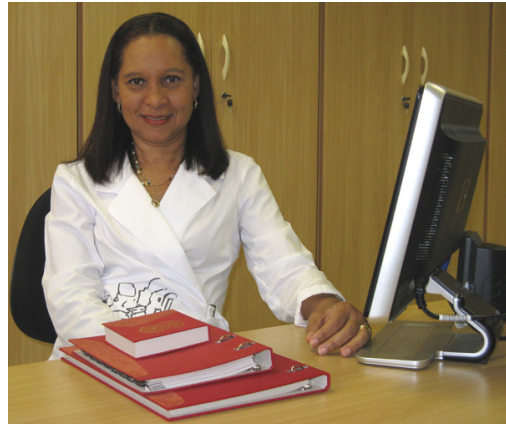

We celebrate, in 2010, the centenary of the death of Florence Nightingale (1820-1910) and to commemorate this historical fact, the United Nations have proposed the "International Year of the Nurse", as an initiative to "give credit to the voices, values and knowledge of these professionals", past and present, who have demonstrated how individual and collective actions can make the "world more healthy and dignified"(1-2).

An important instrument for the mobilization of nurses worldwide, for the success of this recognition, was the "Nightingale Declaration for Our Healthy World", signed by millions of nurses, educators, professionals and caregivers in the area of health worldwide, including Brazil. This movement has continuity, since the declaration will also be used as the cornerstone of a long term, global campaign for the "Mobilization of Public Opinion on Health of Nations", necessary to achieve the goal of a healthy world by 2020, the year that will commemorate the bicentennial of the birth of Florence Nightingale.

Florence Nightingale has been revered for decades for her contributions to knowledge, education and the practice of nursing, as well as for her health care reforms. She pioneered the application of Epidemiology and Statistics in the field of health care. In the case of Statistics, she considered it essential to understand social problems and sought to introduce the study of this branch of knowledge to justify her conclusions in the health field, for example, using the graphical illustration to present the results of her research(3).

It is undeniable that her contributions to human health remain relevant and current. In the book Notes on Nursing, published in 1859, the editor states that "what remains true and current is the essence of the book", i.e. the fundamentals of Florence regarding the need for cleanliness in the water, the air, the environments, the people and clothes; for silence, light and order in the room of the sick and in the nurse, "intelligence, rationality, sensitivity and decency, the ability to show real interest in the patient". In conclusion the editor mentions the fact that such knowledge "will never be considered outdated"(4).

Notes on Nursing is not a manual of techniques, but rather a work that presents the fundamentals of nursing, these fundamentals are supported in a permanent reflection about care and ways of preserving health ${ }^{(4)}$. Florence said that human beings have a vital power and carried out assistance in order to potentiate it.

According to Florence, in the true $\mathrm{ABC}$ of the education of a nurse, the " $\mathrm{A}$ " should be the knowledge about what a sick human being is, the " $B$ " is to know how to behave with a sick person and the " $C$ " is to know that your patient is a sick human being, not an animal(4). 
The elaboration, by Florence Nightingale, of the first theoretical assumptions that guided the profession, transforms the practice of the nurse, basing it on a "coherent, articulate and explicit theoretical concept", marking for nursing, the initiation of a specific body of knowledge through research that grows and changes ${ }^{(5)}$.

The Latin American Journal of Nursing fulfils its role of continuously contributing to the understanding of "what nursing care is".

\section{References}

1. Nightingale Declaration [Internet]. Nightingale Initiative for Global Health. The Nightingale Initiative of Global Health (NIGH): Building A Worldwide Movement [cited 2010 May 28]; [about 2 screens]. Available from: http://www.nightingaledeclaration.net/ 2. 2010 International - Year of the Nurse [Internet]. The Honor Society of Nursing, Sigma Theta Tau International. Florence Nightingale's Relevance for today [cited 2010 May 28]; [About 2 screens]. Available from: http://www.2010iynurse.net/Florence_Nightingale. aspx

3. Carraro TE. Os postulados de Nightingale e Semmelweis: poder/vital e prevenção/contágio como estratégias para a evitabilidade das infeç̧ões. Rev. Latino-Am. Enfermagem. 2004; 12(4):650-7.

4. Nightingale F. Notas sobre enfermagem: o que é e o que não é. São Paulo: Cortez; 1989.

5. Angerami ELS, Mendes IAC. O saber, a saúde e a investigação em enfermagem. Rev. Gaúcha. Enferm. 1989; 10(1):28-33.

Regina Aparecida Garcia de Lima is member of the Editorial Board of the Latin American Journal of Nursing, and Full Professor of the University of São Paulo at Ribeirão Preto College of Nursing, WHO Collaborating Centre for Nursing Research Development, Brazil, e-mail: limare@eerp.usp.br. 